\title{
A Hyperparasite Mistaken for an Inflorescence: The Identity and Typification of Phoradendron rusbyi Britton (Viscaceae)
}

\author{
Job Kuijt \\ Missouri Botanical Garden; Mailing address: Department of Biology, University of Victoria, \\ Victoria, B.C. V8W 2Y2, Canada
}

Abstract. The type of Phoradendron rusbyi Britton (Viscaceae) consists of two species of Phoradendron, one hyperparasitic on the other. The hyperparasite is designated to be the type; the host mistletoe is $P$. crassifolium (DC.) Eichler.

The protologue of the Bolivian Phoradendron rusbyi Britton (in Rusby, 1900; not to be confused with $P$. rusbyanum Trelease) has been puzzling in the past in that it seemed to be made up of discordant elements. Britton described leaf shape, while the rather fragmentary types at NY are strictly squamate. The species is exceedingly rare, being known only from the type collection. Inspection of the types at NY and US, however, has provided a solution to the problem.

It turns out that, unwittingly, Britton was dealing with one species of mistletoe hyperparasitic on another, a situation elsewhere known both in Phoradendron and the closely related Dendrophthora. Thus, part of his protologue describes the leaves of the host mistletoe, the well known Phoradendron crassifolium (DC.) Eichler, and part of it (the "inflorescence") applies to the hyperparasite. We thus have what Article 7B.5 of the International Code of Botanical Nomenclature (Greuter et al., 1988) calls "two or more heterogeneous elements" being fused into a single protologue. This situation requires, among other things, a decision on typification. The Code (Art. 9.2), in such cases, prescribes that the proposed name "must remain attached to that part (lectotype) which corresponds most nearly with the original." In the particular case at hand, however, it is debatable whether the features belonging to one or the other species predominate in the original description. Also, since the application of Britton's name to the older P. crassifolium would then necessitate a new name for the hyperparasite, that course of action would be unfortunate. I therefore here designate Britton's name to apply to the squamate hyperparasite, not to the host mistletoe. In order to clarify the situation, I add an illustration (Fig. 1) of the reconstructed US lectotype as well as a brief new diagnosis of $P$. rusbyi.
Phoradendron rusbyi Britton, Bull. Torrey Bot. Club 27: 136. 1900. TYPE: Bolivia. Mapiri, 5,000 ft., Apr. 1886, Rusby 1543 (lectotype, designated here, US; isolectotypes, NY (2)).

Small, squamate species, internodes to $4 \mathrm{~cm}$ long, extremely compressed, to $1.3 \mathrm{~cm}$ wide, cuneate in shape, in alternating planes from internode to internode. Lateral branches without basal cataphylls, the first leaf scales in median position. Probably monoecious, the male flowers fewer than the female and higher on fertile internodes (?). Inflorescences both lateral (where apparently solitary) and terminal, at least $4 \mathrm{~cm}$ long, peduncle $3-5 \mathrm{~mm}$, stout, simple, followed by at least 4 fertile internodes, flowers to ca. 15 per fertile bract, triseriate, the fertile internodes stout but not clavate. Fruit globular, ca. 2.5 mm diam., petals closed.

Britton placed his new species in Phoradendron, but in the monograph of this genus by Trelease it is referred to Dendrophthora without discussion (Trelease, 1916: 218). It is almost certain that Trelease did not study the crucial anther morphology, as I know of no reference to this, the most important generic distinction, in any of his publications. It may well be that he was guided in his placement by the fact that lateral branches of $P$. rusbyi lack any basal cataphylls. The primary division of Phoradendron in Trelease's treatment was according to whether basal cataphylls were or were not present, the acataphyllous "Boreales" supposedly not occurring further south than southern Mexico. In point of fact, a number of exceptions to this simple dichotomy of the genus are now known (unpublished information). More relevant to the present species is the fact that the absence of cataphylls by itself cannot reliably be used for generic placement. Unfortunately, I have not been able to find mature male flowers.

Notwithstanding the absence of basal cataphylls, I feel that the likelihood of the species being a Phoradendron outweighs the other option. The extreme reduction of the plant may well mean that its hyperparasitism is obligatory. There is a group of 


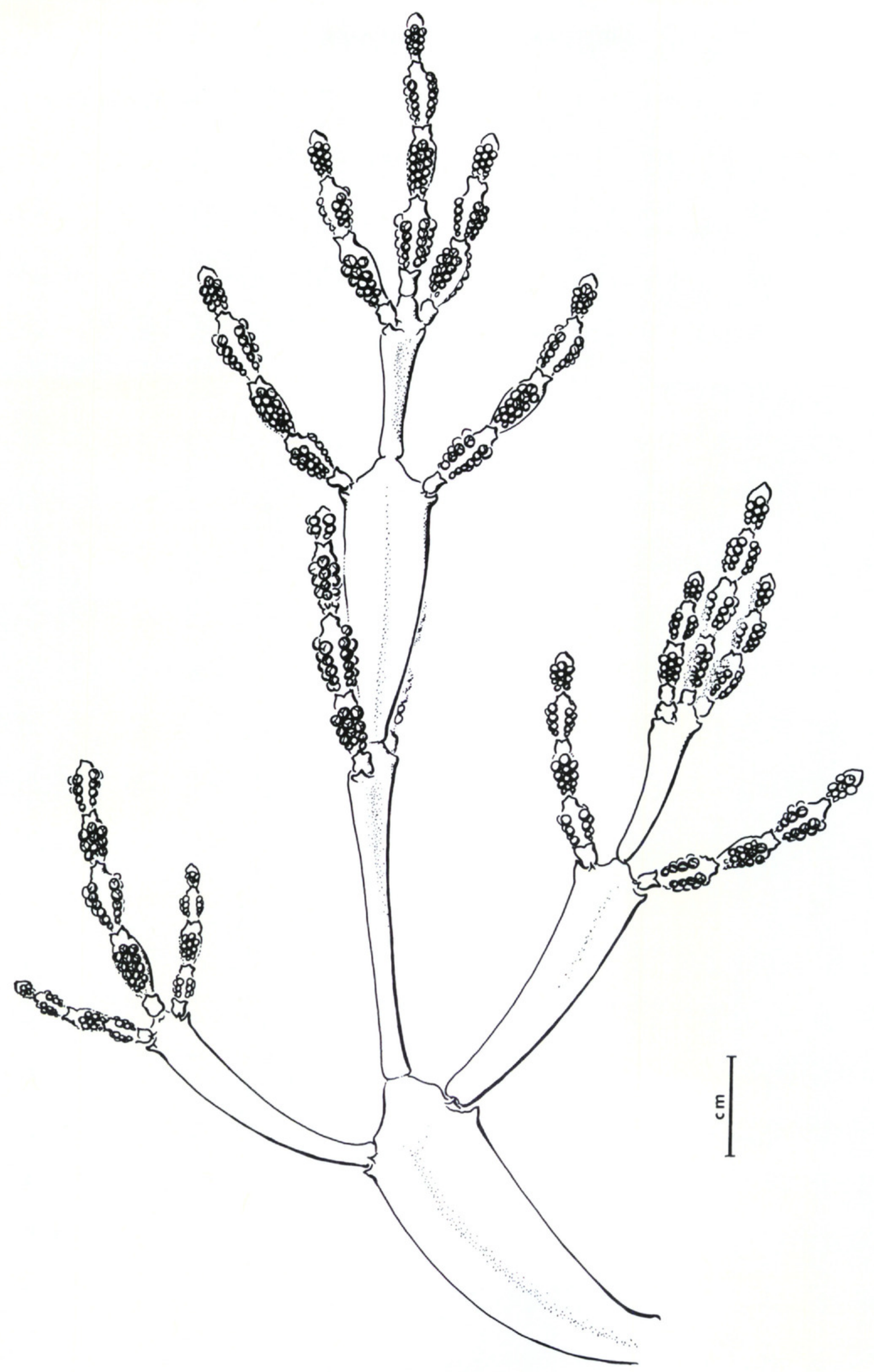

Figure 1. Reconstruction of Phoradendron rusbyi Britton from the lectotype at US. Scale bar $=1 \mathrm{~cm}$. 
largely or exclusively hyperparasitic species of Phoradendron in Central and South America with a strong tendency to leaf reduction and flattened or winged internodes. The common, leafy $P$. dipterum Eichler is a well known member of this group; aphyllous species are $P$. iltisiorum Kuijt and $P$. aequatoris Urban, while P. fasciculatum Kuijt is nearly leafless. These species are also characterized by the emergence of several shoots from a haustorial cushion connecting the two mistletoes (see Kuijt, 1987 , fig. 6). One of the two NY types clearly has such a cushion and emergence pattern. Even more interesting is the fact that at least one species of this complex, P. calyculatum Trelease, has lost its basal cataphylls, and that because of this, the species has traditionally been misplaced in "Boreales." My assumption is, therefore, that $P$. rusbyi is yet another acataphyllous member of this group of hyperparasites. No hyperparasitism is known to occur in continental Dendrophthora. However, a rare Cuban endemic, D. epiviscum (Grisebach) Eichler, parasitizes other species of Dendrophthora or Phora- dendron (Kuijt, 1961). The two species, even in the absence of male flowers, may be easily distinguished by the tetrapterous stems and fewer fertile internodes with no more than seven flowers per bract in D. epiviscum.

\section{Literature Cited}

Greuter, W., H. M. Burdet, W. G. Chaloner, V. Demoulin, R. Grolle, D. L. Hawksworth, D. H. Nicholson, P. C. Silva, F. A. Stafleu, E. G. Voss \& J. McNeill. 1988. International Code of Botanical Nomenclature. Regnum Veg. 118.

Kuijt, J. 1961. A revision of Dendrophthora. Wentia 6: $1-145$.

— 1987. Novelties in Mesoamerican mistletoes (Loranthaceae and Viscaceae). Ann. Missouri Bot. Gard. 74: 511-532.

Rusby, H. H. 1900. An enumeration of the plants collected by Dr. H. H. Rusby in South America, 1885-1886, xxx. Bull. Torrey Bot. Club 27: (see p. $136-137)$.

Trelease, W. 1916. The Genus Phoradendron. Univ. Illinois Press, Urbana, Illinois. 


\section{$2 \mathrm{BHL}$ Biodiversity Heritage Library}

Kuijt, J. 1994. "A hyperparasite mistaken for an inflorescence: The identity and typification of Phoradendron rusbyi Britton (Viscaceae)." Novon a journal of botanical nomenclature from the Missouri Botanical Garden 4, 116-118. https://doi.org/10.2307/3391580.

View This Item Online: https://www.biodiversitylibrary.org/item/14664

DOI: https://doi.org/10.2307/3391580

Permalink: https://www.biodiversitylibrary.org/partpdf/20921

\section{Holding Institution}

Missouri Botanical Garden, Peter H. Raven Library

\section{Sponsored by}

Missouri Botanical Garden

\section{Copyright \& Reuse}

Copyright Status: In copyright. Digitized with the permission of the rights holder.

License: http://creativecommons.org/licenses/by-nc-sa/3.0/

Rights: https://biodiversitylibrary.org/permissions

This document was created from content at the Biodiversity Heritage Library, the world's largest open access digital library for biodiversity literature and archives. Visit BHL at https://www.biodiversitylibrary.org. 